\title{
2. Legal formalism versus pragmatism
}

\section{INTRODUCTION}

Many legal scholars would be unsurprised by the statement that in deciding whether to refer, courts are merely applying the law. For them, it is a given that courts refer to the ECJ in an effort to comply with their obligations under EU law as set out in the Treaties. Adopting a legal-formalist perspective, one would emphasize that courts conduct a legal assessment of the clarity of the question of EU law and aim to abide strictly by the CILFIT requirements. Most judges interviewed emphasized that a referral is made simply because there is uncertainty regarding the meaning of a particular provision - for example, because it is used in contradictory ways in the EU rules or has not yet been interpreted by the ECJ. ${ }^{1}$ One example is the case of $Z h$ and $O$, in which it was unclear whether there were differences in the interpretation of 'public order' for EU citizens and third-country nationals. ${ }^{2}$ Much of the politically inspired research to date fails to acknowledge that most of the questions referred entail rather 'boring' legal technicalities - for example, the tariff classification of goods or undefined terms in EU legislation - instead of politically sensitive issues on which national law is not in line with EU law. The judges interviewed also emphasized this point. Many held that the main reason to refer is that it is too difficult for the national court to decide a legal question. One illustration of this legal-formalist logic is the reference made in Nutricia. The UK High Court held that there was real doubt as to the meaning of the term 'food for medical purposes'. It noted that the definition was very broad and imprecise, and was 'susceptible to a number of differing interpretations'. It subsequently pointed to more than a handful of terms with a multiplicity of meanings. ${ }^{3}$ Another example is the technical case of Nannoka Vulcanus Industries, where the Dutch Council of State was confronted with a legally complex annex to Directive 1999/13/EC on the limitation of emissions of volatile organic compounds due to the use of organic solvents in certain activities and installations.

\footnotetext{
1 Interviews 10, 43, 66, 72, 83, 89, 91, 208. Cf Fusco 2015, 1535.

2 Case C-554/13 Zh and $O$ EU:C:2015:377.

3 Nutricia Ltd $v$ The Secretary of State for Health [2015] EWHC 2285 (Admin), paras 20 and 213; Case C-445/15 Nutricia EU:C:2016:106.
} 
The legal questions about the meaning of, among other things, the concepts of 'time extension' and 'installation' were simply too difficult for the Council to grasp on its own. ${ }^{4}$

This legal view has been supported by scholars and judges alike, who have emphasized that courts are pragmatic and refer (or not) in order to solve a dispute efficiently. Several (lower) courts pay little attention to the question of whether they are obliged to refer and simply reason along the following lines: 'we are not able to reach a decision on this appeal without further guidance from the ECJ'. ${ }^{5}$ Courts thus decide whether a reference is 'worth the effort' and weigh different considerations, including the importance of the question and expected delays. From this perspective, it is unsurprising that courts are generally reluctant to refer and adopt a pragmatic reading of CILFIT.

This chapter shows that there is a fine line between legal formalism and pragmatism. It is a spectrum across which courts and judges operate differently, depending on the case at hand. Chambers and judges within courts also have different perspectives; and it is a fiction that courts, as such, can be reduced to being purely formalist or pragmatic. This is nonetheless what this chapter will assume, not least for the sake of readability. Section 2 primarily focuses on courts that, overall, strictly adhere to the Article 267 framework and CILFIT, such as the Irish Supreme Court and the two Irish intermediate appellate courts (the Court of Appeal and the High Court), as well as the Dutch Supreme Court (except the Criminal Chamber). Section 3 discusses the lower courts in all three jurisdictions, as well as the UK Supreme Court and the Dutch highest administrative courts. This division implies that the situation is very much black and white among the various levels. In reality, there are obviously grey areas and nuances among the courts. The different courts have been chosen to highlight the differences and show that both perspectives inform various parts of the referral practice.

\section{LEGAL FORMALISM: CONSCIENTIOUS COURTS}

\subsection{Natural Conscientiousness: Contributing to the Development of EU Law}

One explanation for the differences in the number of references between EU Member States and the decisions of individual national courts to refer is the court's responsibility for the correct application of EU law, as well as the

Case C-81/14 Nannoka Vulcanus Industries EU:C:2015:575; Interview 91. Invamed Group Ltd \& Ors v HMRC [2015] UKFTT 113 (TC), para 223. 
desire to contribute to the development of EU law. ${ }^{6}$ Most Dutch Supreme Court judges mentioned the obligation to refer under Article 267 TFEU as an essential aspect of their decision to refer. ${ }^{7}$ Dutch Supreme Court judges referred - sometimes multiple times in one interview - to the Supreme Court's '(natural) loyalty' and its 'conscientiousness' ${ }^{8}$ This responsibility was mentioned less often by some Dutch highest administrative court judges and especially UK judges. This is not to say that the latter disrespect their obligation to refer; but as will be discussed in section 3, these more pragmatic judges pointed to a 'natural reluctance' to refer.

Closely related to the conscientious application of EU law and Article 267 TFEU is the desire to contribute to the development of EU law. Several Dutch Supreme Court judges mentioned this as a general consideration in their decision to refer. ${ }^{9}$ One judge, for example, noted: 'You are not here for yourself, but also for the rest of Europe.' ${ }^{10} \mathrm{He}$ /she mentioned that the Supreme Court judges widely share the view that it is important that EU law achieve its full potential. According to him/her, the delay of 1.5 years as a result of a reference should be taken for granted and is 'the price that is paid' for participation in the EU system. ${ }^{11}$ Another interviewee referred to the 'sense of responsibility' and the role of the Supreme Court as a 'wheel in the gear chain' of the European legal order; while another stressed the importance of the uniformity of EU law and the need to avoid divergences in the interpretation of EU law across Member States ('one of the most severe sins'). ${ }^{12}$ A few Dutch highest administrative court judges also made similar remarks about the need to contribute to the development of EU law, but noted at the same time that the primary purpose of the procedure is to resolve disputes. ${ }^{13}$ As will be outlined in section 3 , most judges of the highest administrative courts tend to avoid making a reference and prefer to decide cases themselves. ${ }^{14}$

Compared to the Dutch and Irish Supreme Courts, the UK courts do not appear to be as anxious to contribute to the development of EU law so that it achieves its full potential. Instead, there are concerns about far-reaching intrusions by the EU into the common law system and a desire to preserve the national system (see Chapter 4, section 2). In addition, there is a strong

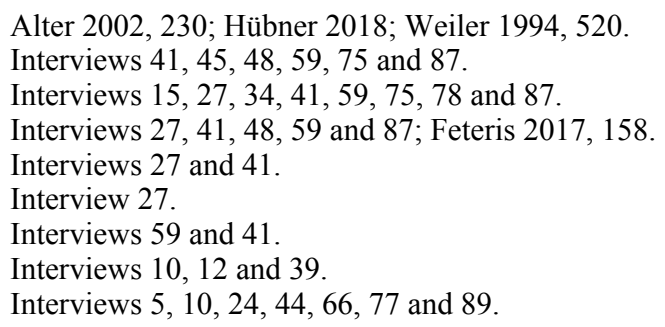


desire in the UK Supreme Court to interpret EU law by itself. Lord Reed, for example, pointed to the Supreme Court's 'own responsibility to uphold our constitution' and mentioned Article 4(2) of the Treaty on European Union (TEU) on national identities. ${ }^{15}$ According to Reed, the fact that apex courts 'patrol' the limits of EU law is a good thing. ${ }^{16}$ There is a desire to contribute to the EU legal system, but primarily as a way to exercise influence and preserve the UK legal system. Lady Justice Arden, for example, stressed the need for national courts to 'assert themselves if they are going to stand any chance of influencing the development' of EU law. ${ }^{17}$ She added:

[I]t is my firm view that in order to retain the integrity of our own legal system we must ensure that our domestic law is properly understood in Europe and that we are able to influence EU law's development. ... English law is a valuable asset which we should use to best advantage. ${ }^{18}$

As will be discussed in section 3.4, the UK courts are aware of the importance of ensuring the uniformity of EU law, but primarily as a domestic commercial interest.

\subsubsection{Highest courts: strict application of CILFIT}

Those courts that feel a responsibility to ensure the correct application of EU law have, by and large, applied CILFIT strictly. This stands in contrast to the Dutch highest administrative courts and the UK Supreme Court, both of which applied a 'lighter test' than CILFIT and argued that it is not necessary to refer immediately if there is some doubt about the interpretation of EU law (section 3.2). Dutch and Irish Supreme Court interviewees did not agree and sometimes vehemently rejected this suggestion. ${ }^{19}$

The Irish Supreme Court has adhered strictly to CILFIT in recent years, as was acknowledged by Irish lower court judges and other interviewees. ${ }^{20}$ One Irish Supreme Court judge stated that the Supreme Court is 'very, very cautious' in case of any doubt. ${ }^{21}$ Another judge observed, '[B]y and large, when we think it is referable, off it goes' - even if the majority of judges think that a reference is not required..$^{22}$ This caution was attributed to some unanticipated replies by the ECJ that diverged from the (outvoted) majority which initially

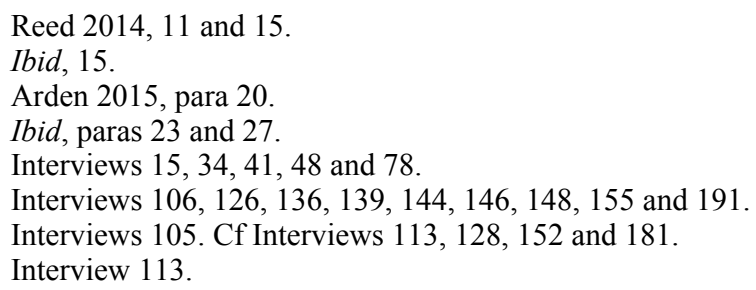


were against a reference. ${ }^{23}$ When confronted with the pragmatic application of CILFIT by some of the Dutch highest administrative courts, one Supreme Court judge noted: '[W]e have to err on the side of caution. ${ }^{24}$ If one or two of the five judges think that a reference is necessary, the court tends to refer out of 'internal respect'. ${ }^{25}$ It is perhaps unsurprising that one judge acknowledged that the court may well refer too often and argued: 'The European system cannot continue to insist that everyone is as loyal as we are, otherwise the ECJ would be swamped by cases. ${ }^{26}$

One good illustration of the cautious approach of the Irish Supreme Court is James Elliott Construction, concerning the EU legal status of harmonized technical standards for construction products and their relevance in contractual relationships between two private parties. The Supreme Court discussed CILFIT extensively in its decision to refer. ${ }^{27}$ The Court decided to refer in order to err on the side of caution. ${ }^{28}$ There was a feeling that the Supreme Court could have decided the questions itself and would have reached the same conclusion as the CJEU. It nonetheless felt obliged to refer in the light of the CILFIT test, even though the delay caused by the referral had negative consequences for the housing company involved. ${ }^{29}$ One interviewee explained that this case was referred because one learned academic ('who could not be dismissed as being simply extreme or provocative') had stated that there might be an incompatibility with EU law. This possibility could not be excluded altogether.

Dutch Supreme Court judges generally reasoned in the same way, with the exception of those in the Criminal Chamber. One Dutch Supreme Court interviewee cautioned: 'You should not think too quickly that we can decide ourselves with five sensible persons. ${ }^{30}$ The same judge held, in response to criticism of the referral of the relatively straightforward case of Massar, that the concern is that an EU law expert might subsequently criticize the Supreme Court for non-referral (see Chapter 4, section 3). ${ }^{31}$ Another judge proposed a strict application and suggested, in line with CILFIT, that the Supreme Court

23 This happened in as least three cases - Case C-164/17 Grace and Sweetman EU:C:2018:593, Case C-413/15 Farrell EU:C:2017:745 and Case C-428/15 D. EU:C: 2016:819; Interviews 152 and 181.

24 Interviews 128 and 152. Cf Interview 105.

25 Interview 152.

26 Interview 113.

27 James Elliot Construction v Irish Asphalt Ltd [2014] IESC 74, paras 154-59,

184; Case C-613/14 James Elliott Construction EU:C:2016:821.

28 Interview 128.

29 Interview 113.

30 Interview 27.

31 Case C-460/14 Massar EU:C:2016:216; Interview 27. 
should be 'convinced' that there is no doubt about the interpretation of EU law. $\mathrm{He} / \mathrm{she}$ rejected the logic of some highest administrative court judges that no reference is needed where the question is 80 per cent clair and argued that the CILFIT criterion is not whether the court can come up with a solution itself. ${ }^{32}$ The Supreme Court hence prefers to play it safe. This strict application is also reflected in the generally low number of case law comments and articles criticizing the Dutch Supreme Court for non-referral. ${ }^{33}$ The Tax Chamber is even more faithful to CILFIT than the Civil Chamber. The Tax Chamber does not necessarily first consider whether the case can be disposed of on other (national) grounds before applying the CILFIT test. One judge interviewed indicated that even if the question can be dealt with nationally, the court will still ask, 'Do we want that?' and 'How sure are we about our interpretation?' ${ }^{34}$ The Tax Chamber also examines a wide variety of sources on its own initiative to establish whether there is doubt, such as the decisions of courts in other EU Member States, different language versions of EU legislation and German and French legal literature. ${ }^{35}$ Examples of references on the side of caution involve customs classification cases such as Sonos and Sprengen, which respectively concerned standalone devices that stream and amplify sound and devices that store and reproduce multimedia files on a video monitor. ${ }^{36}$ The Tax Chamber decided to refer both cases even though the two courts of first instance and the AG were aligned. One could thus argue that the answer to the legal question was clear. This was also suggested by a lower tax court judge, who mentioned that the ECJ subsequently responded with the implicit message, '[A]re you there already again?' because the ECJ handled the references with a three-judge formation without an AG Opinion. ${ }^{37}$ There has recently been a slight change in the thinking of (some) tax law judges, who are advocating for a more pragmatic application of CILFIT and calling for more 'courage' in interpreting EU law themselves. ${ }^{38}$

32 Interview 82.

33 The more faithful approach of the Supreme Court does not mean, however, that there are no cases which were not referred to the ECJ, but should have been. One example relates to litigation cost orders in IP cases, Vrendenbarg 2018, 220-223. Cf Interview 48; Knooble/Staat and NNI NL:PHR:2012:BW0393, para 5.10. Another exception relates to the distinction between 'infringements by object' and 'infringements by effect' in competition law, Case C-226/11 Expedia EU:C:2012:795; Claassen 2019.

34 Interview 30. Cf Interview 34.

35 Interviews 15, 30, 33, 34 and 82 .

36 Case C-84/15 Sonos EU:C:2016:184 and Case C-97/15 Sprengen EU:C:2016: 556.

37 Interviews 35 and 65.

38 Interviews 30 and 78; Eg NL:HR:2018:862. 
There are various explanations for the cautious approach and strict application of CILFIT by the Civil and Tax Chambers of the Dutch Supreme Court and the Irish Supreme Court. First, both courts handle a relatively small number of cases, an even smaller number of which involve EU law questions. For example, the judges interviewed from the Civil Chamber of the Dutch Supreme Court suggested that out of an average of 500 cases per year, an estimated 10 per cent have an EU law dimension. Even fewer cases raise the issue of whether to ask questions, because in many cases there are no ambiguities about the interpretation of EU law. ${ }^{39}$ The relatively small case docket of these courts can be contrasted with the caseload of the Dutch Council of State and the Criminal Chamber of the Dutch Supreme Court. Some interviewees noted that the Council of State could potentially refer as many as five questions a week. ${ }^{40}$ The Council of State is consequently forced to operate pragmatically and refer only when this is strictly necessary.

A second explanation for the strict application of CILFIT by the Dutch Supreme Court is the role of the AGs. It is obviously more difficult for a court to argue that a reference is not necessary where the AG determines that the matter is not clair. It is therefore unsurprising that interviewees acknowledged that the AG's conclusion that an issue should be referred plays an important role and is sometimes even more important than the submissions of the parties. ${ }^{41}$ In nine of the 12 references of the Civil Chamber in 2013-16, the AG advised the court to refer. In two cases, the AGs advised the court not to refer, since these cases concerned interlocutory proceedings. ${ }^{42}$ The Civil Chamber decided on only four occasions not to follow up on the advice to refer. All four decisions not to refer are rather uncontroversial and were not subject to (much) criticism in the legal literature. One was referred to the Benelux Court instead of the ECJ. ${ }^{43}$ In two others, the question of EU law was not decisive or did not need to be addressed; while in another case the AG 'merely' recommended follow-up questions after the ECJ judgment in Makro. ${ }^{44}$

A third explanation as to why the Tax Chamber adheres to CILFIT so strictly is to prevent lower courts from being tempted to refer. This explanation is consistent with the inter-court competition model of Alter which posits that the highest courts have an interest in limiting references from lower courts

\footnotetext{
Interviews 23, 27 and 75; Polak 2009, 103.

Interviews 27 and 59.

Cf Polak 2009, 107; Interviews 15, 27, 41 and 87.

Connexxion Taxi Services NL:PHR:2014:2001, para 5; Synhton NL:PHR:2016:

${ }_{43}$ Montis Design NL:PHR:2013:1864, paras 5.20-5.23.

${ }^{44}$ AG Verkade in NL:PHR:2013:114, para 4.15; Case C-324/08 Makro EU:C:
} 866, para 4.29. 2009:633. 
(see Chapter 4, section 3). ${ }^{45}$ There have been few references by Dutch lower court judges in the tax law area. ${ }^{46}$ The caution of the Tax Chamber can be attributed to the famous Van der Steen incident. The Supreme Court failed to refer the question as to whether a natural person carrying out all work in the name and on behalf of a company is himself or herself a taxable person within the meaning of the Sixth VAT Directive. The Amsterdam Court of Appeal subsequently referred this question to the ECJ. ${ }^{47}$ The fact that the 'lower' court of appeal had to make up for an error of the Supreme Court was widely seen as an embarrassing episode that should be avoided in future. This explanation coincides with recent studies which indicate that the highest courts have reclaimed control from the lowest courts in relation to the application of EU law and references to the ECJ.48

\subsubsection{Lower courts: de facto obligation to refer}

Lower courts are not obliged to refer on the basis of Article 267 TFEU, as discussed in Chapter 1, section 2. One would thus expect a discussion of their referral practice to take place in the following section on pragmatism. Nevertheless, in particular Irish intermediate appellate courts, such as the Court of Appeal and the High Court, have sometimes applied the CILFIT criteria in the same way as the Irish Supreme Court. The fact that they have merely discretion, and no obligation, to refer thus matters less to them. One High Court judge even suggested that where there is doubt about the interpretation of EU law, the High Court is obliged to refer, in order to avoid a unilateral and possibly incorrect interpretation. ${ }^{49}$ There is a widely shared feeling among Court of Appeal judges that the court is de facto obliged to refer, regardless of the possibility to appeal to the Supreme Court. ${ }^{50}$ The Court of Appeal regards itself as the final court in the sense of Article 267 TFEU, because of the very limited grounds to appeal in practice. ${ }^{51}$ Two judges, for example, noted that the Court of Appeal 'must' make a reference because it cannot assume that

45 Alter 1998, 242; Pavone and Kelemen 2019.

46 Lower courts made two tax law references in 2013-16 and seven references in the field of customs. Six of these seven questions dealt with the validity of EU law which gives rise to an obligation to refer on the basis of Case C-314/85 Foto-Frost EU: C:1987:452.

47 Case C-355/06 Van der Steen EU:C:2007:615.

48 Arnull likewise observed that the UK Supreme Court has engaged with the ECJ in order to prevent it from being marginalized by lower courts' direct dialogue with the ECJ. Arnull 2010, 80; Dyevre et al 2020; Pavone and Kelemen 2019.

49 Interview 161.

50 Interview 108.

51 Since the Court of Appeal commenced operations, the Supreme Court has increasingly become a true Court of Final Appeal with a low number of appeals, 
the case will go to the Supreme Court, so the Court of Appeal will most likely be the final court of appeal..$^{52}$ One Court of Appeal judge argued that where there is a real question of EU law, 'we should go to get a definitive view'; while another acknowledged that 'we look with CILFIT eyes', even though the Court of Appeal is not bound to refer. ${ }^{53}$ For example, the Irish Court of Appeal referred Mahmood, about delays in the processing of visa applications of family members of EU citizens. The court held that its question had 'not yet ... been directly considered by the Court of Justice'. It also pointed to doubts as to the arguments given by the minister for justice and equality and the absence of an acte clair..$^{54}$

The way in which the Dutch and UK lower courts have used their discretion to refer will be discussed in section 3.3, since they primarily highlighted their discretion to refer in judgments and interviews. There have been some UK judgments that tend towards the current position of the Irish Court of Appeal and High Court. The famous position of Sir Bingham in ex parte Else is exemplary. He limited the complete discretion for lower courts and determined:

[I]f the facts have been found and the EU law issue is critical to the court's final decision, the appropriate course is ordinarily to refer the issue to the Court of Justice unless the national court can with complete confidence resolve the issue itself. In considering whether it can with complete confidence resolve the issue itself, the national court must be fully mindful of the differences between national and EU legislation, of the pitfalls which face a national court venturing into what may be an unfamiliar field, of the need for uniform interpretation throughout the EU and of the great advantages enjoyed by the Court of Justice in construing EU instruments. If the national court has any real doubt it should ordinarily refer. ${ }^{55}$

The 'complete confidence' test is arguably more difficult to fulfil than the acte clair test in CILFIT ('so obvious as to leave no scope for any reasonable doubt'), and can thus be said to encourage lower courts to refer more quickly. One good illustration is the reference of the High Court in Rosneft on the basis that it could not be confident that all EU courts would adopt the same conclusions, especially because of the differing views of the authorities in various Member States. ${ }^{56}$ UK (intermediate appellate) courts nonetheless do

Geoghegan 2017, 28. A reference was 'required' in Danqua v Minister for Justice [2015] IECA 118 (Hogan J), para 43.

52 Interview 166, 174. Cf Interview 191.

53 Interview 108, 174.

${ }_{54}$ Mahmood \& Anor v Minister for Justice [2018] IECA 3 (Hogan J), para 61.

55 Sir Bingham in $R v$ International Stock Exchange ex parte Else Ltd [1993] QB $534,545 \mathrm{D}$.

56 PJSC Rosneft Oil Co v HMRC [2015] EWHC 248 (Admin), paras 30-31. Cf McCarthy \& Ors, $R$ (on the application of) $v$ SSHD [2012] EWHC 3368 (Admin), paras 110 and 112. 
not go as far as their Irish counterparts in seeing themselves as de facto the highest courts and therefore obliged to refer, as will be further discussed in section $3.3 .{ }^{57}$

\subsection{Pragmatism: Pragmatic Courts}

The courts that have not applied CILFIT strictly - such as the Dutch highest administrative courts, the Dutch lower courts and (almost) all UK courts have primarily observed pragmatic considerations in their decisions (not) to refer. The more pragmatic application of CILFIT also allows for other considerations to be taken into account and shifts the question of whether a reference is required to a question about whether it is appropriate to refer. Lady Justice Arden, for example, considered in Sanneh that it would not be 'right' to refer, even though the answers were not acte clair. ${ }^{58}$ Lord Phillips reasoned similarly in Abbey National and found the issue not to be clair, but held that 'it would not be appropriate to refer' ${ }^{59}$ The decision on whether a reference is appropriate involves pragmatic considerations that act as a filtering mechanism which prevents those courts from referring all questions that may arise too quickly. These include, for example, case-specific reasons that relate to the importance of the questions concerned (section 3.4) and efficiency reasons concerning the consequences of referring in terms of the delay (section 3.5).

\subsubsection{Natural reluctance}

All national court judges exhibit a general initial reluctance to refer - even the 'conscientious' courts discussed in the previous section. This reluctance is strongest in the UK courts and the Dutch highest administrative courts. ${ }^{60}$ The same holds true for most lower court judges in all three countries. Lord Neuberger, for example, noted in one case that had the issue been determinative, he would have 'very reluctantly' concluded that a reference was needed. ${ }^{61}$ Lord Carloway, lord president of the Scottish Court of Session, similarly noted that his court was 'anxious, whenever possible, to resolve disputes which

57 However, 'if I had found the issue was not acte clair, the fact that I am considering the case at the level of the Upper Tribunal would not matter', Lim v Malaysia [2013] UKUT 437 (IAC), para 32.

$58 \quad$ Sanneh \& Ors $v$ SSWP [2015] EWCA Civ 49, paras 125 and 172.

59 Office of Fair Trading (OFT) v Abbey National plc \& Ors [2009] UKSC 6, para 91 (Lord Phillips).

60 Heyvaert et al 2014; Golub 1996.

${ }_{61}$ Office of Fair Trading (OFT) v Abbey National plc \& Ors [2009] UKSC 6, para 120 (Lord Neuberger). 
involve aspects of EU law without troubling the ECJ'. ${ }^{62}$ Several of the Dutch highest administrative court judges have likewise held that there is no need to instantaneously refer in case of the slightest doubt about the interpretation of EU law. Otherwise, a reference would be made on a weekly basis, especially in fields such as migration. ${ }^{63}$ Judges from the Dutch Trade and Industry Appeals Tribunal observed in a similar vein that an estimated 80 per cent of cases deal with EU law, and it would thus be unfeasible always to refer in case of doubt. ${ }^{64}$

There are several explanations for the reluctance of these courts to refer. First, the consequences of referring, in terms of the costs and the impact both on the parties and on other cases, are significant. Judges are aware that references are time consuming and expensive, as a result of which a reference is made only when really necessary. ${ }^{65}$ One Dutch judge, for example, stated that formulating a preliminary reference is as difficult as answering it. ${ }^{66}$ The UK Court of Appeal also applies a high threshold in order to justify 'an expensive and time consuming reference' ${ }^{97}$ There is a desire not to introduce an extra stage to the proceedings and impose delays on the parties, as well as to avoid other cases being put on hold (section 3.5). ${ }^{68}$

Second, referring a case to another higher international court can run counter to judges' professional attitudes. The first instinct of judges of the Dutch highest administrative courts is to resolve disputes and decide themselves. One UK judge suggested that it is 'frustrating to send it off for someone else to decide', not least because you are 'wasting' the time of the other court. ${ }^{69}$ This was also noted by a UK barrister, who stated that the fundamental attitude of judges is to 'go for it' themselves. ${ }^{70} \mathrm{He} /$ she also suggested that the training of UK judges discourages them from asking for help unless they are absolutely unsure. He/she noted that this is strongly ingrained in the minds of UK judges, while continental judges might have more of a civil service mentality and a heightened sense of hierarchy. ${ }^{71}$ Lord Mance reasoned, in a similar fashion, that 'judges are trained to make up their own mind', which 'can impart a beguilingly dangerous certainty'.72

\footnotetext{
${ }^{62}$ Sanneh \& Ors $v$ The Secretary of State [2018] CSIH 62, para 30. Cf Rodger 2017.

Interviews 5, 10, 18, 44, 66, 72, 77, 81 and 89. Cf Bobek 2020, 89.

Interviews 31, 32, 66, 69 and 89; Sevenster and Wissels 2016, 90.

Interviews 24, 39, 66, 81 and 264.

Sevenster 2011, 301.

Bloy \& Anor v Motor Insurers' Bureau [2013] EWCA Civ 1543.

Interviews 14, 39, 83 and 264; Sevenster and Wissels 2016, 90.

Interview 231.

Interview 276.

Ibid.

Mance 2013a, para 25.
} 
Third, there appears to be a general concern about the workload of the ECJ. However, the real question here is whether national judges are sincerely concerned about this issue or whether they are rather using it as a fig leaf to avoid a reference. It is likely that the answer is a combination of both. Some judges interviewed noted that a reluctance to refer is also in the interests of the ECJ itself. ${ }^{73}$ One Dutch judge observed that if all judges in the EU were to make the same amount of references as Dutch judges, the ECJ would be overburdened. ${ }^{74}$ The UK judges who were interviewed were also conscious of not overloading the ECJ and 'not wasting someone else's time'. ${ }^{75}$ One UK judge suggested that the ECJ had sent an 'unofficial message' of 'only referring if you really have to' ${ }^{76}$ Another UK judge maintained that the ECJ would be surprised if CILFIT were taken literally; if the ECJ really meant what it said, this would lead to a huge amount of cases. ${ }^{77}$ Lord Reed argued that a reference 'cannot be made whenever a point of EU law arises, without bringing the system to its knees' ${ }^{78}$ He considered it a 'mistake' to do so, even where it is not obvious how a case should be decided. ${ }^{79}$ The workload of the ECJ was mentioned in several UK judgments as a reason not to refer. ${ }^{80} \mathrm{~A}$ similar reason not to refer, which the High Court cited in Tomanovic, was the 'use of the Court's resources'. ${ }^{81}$ Interviews conducted with Swedish judges likewise revealed that the fear of overburdening the ECJ discouraged references. ${ }^{82}$

There is a fourth explanation for the reluctance of UK courts in particular to refer: the rather negative views about the procedure as a result of (previous) references. As will be discussed further below, there has been a growing tendency to 'shield' references from the ECJ as a result of negative feedback loops (see Chapter 4, section 2 and Chapter 8, section 1.4). Lord Millett sees referring as 'a required duty rather than an attempt to achieve any meaningful understanding of EU law' - not least because he 'never quite knows what to ask' to get the details of EU law. ${ }^{83}$ Other judges interviewed by Littlepage

\footnotetext{
Interviews 5 and 18; Sevenster 2011, 299.

Interview 18.

Interviews 208 and 231 respectively.

Interview 231. Cf Arden 2015, para 16.

Interview 264.

Reed 2014, 2. Cf Mance 2013a, para 25.

Reed 2014, 6.

$80 \mathrm{Eg}$ European Federation for Cosmetic Ingredients $v$ The Secretary of State for Business, Innovation and Skills and Attorney General [2014] EWHC 4222 (Admin), para 28; Daimler AG v MOL (Europe Africa) Ltd \& Ors [2019] EWHC 3197 (Comm),

81 Tomanovic \& Ors $v$ The European Union [2019] EWHC 263 (QB), para 92.

82 Leijon 2020; Leijon and Glavina 2020.

83 Interviewed 10 December 2012 as quoted by Littlepage 2014, 205-06.
} para 132. 
in 2012 discussed the procedure in similar terms. ${ }^{84}$ That said, not all judges interviewed were or openly and overtly resistant to the ECJ; one UK judge ('an admirer') applauded the 'beauty of the system', which he/she considered 'first class'. He/she came to this realization as a result of several cases before the House of Lords about the Warsaw Convention and the liability of airline carriers, in relation to which there is no international court that could provide a definitive interpretation that would be binding all Member States. ${ }^{85}$

\subsubsection{Highest courts: pragmatic reading of CILFIT}

The reluctance to refer has resulted in two interrelated phenomena: a pragmatic or reasonable reading of CILFIT; and a preference for resolving the dispute on other (national) grounds in order to avoid a reference.

With respect to the former, the UK Supreme Court and the Dutch highest administrative courts have adopted a pragmatic reading of CILFIT. Several Dutch judges, for example, proposed a 'lighter test' than CILFIT and held that where the question is $75-80$ per cent clair, there is no need to refer ${ }^{86}$ The question is not only whether there is doubt, but also whether the reference is 'worth the effort' ${ }^{87}$ Some highest administrative court judges even acknowledged that they (implicitly) apply the less strict Köbler 'test' in order to prevent a non-referral from giving rise to state liability 'in the exceptional case where the court has manifestly infringed the applicable law' ${ }^{88}$ Likewise, the UK Supreme Court recently stipulated that it does not adopt 'a mathematical approach to whether something is or is not acte clair or acte éclairé'. ${ }^{89}$ It has sometimes held that where the court is unanimous, this means that the point is clair. ${ }^{90}$ One former UK Supreme Court judge made similar arguments to

$84 \quad$ Ibid, 206.

85 Interview 208.

86 Council of State judges referred to the test of whether the matter is 'sufficiently, albeit not entirely but to a considerable extent, clair or éclairé', Interviews 44 and 72; Sevenster and Wissels 2016, 91. Eg NL:CBB:2017:179, para 4.7.

87 Interviews 18, 44 and 72; Sevenster 2011, 297.

88 Interviews 10 and 18; Case C-224/01 Köbler EU:C:2003:513, para 53. Note that some AGs of the Civil Chamber also rely on this test in some opinions. Eg Stichting Brein NL:PHR:2015:729, para 2.1.34.

89 Written response 15 April 2020.

90 Office of Fair Trading (OFT) v Abbey National plc \& Ors [2009] UKSC 6, para 49; A (Children), Re (Rev 1) [2013] UKSC 60, para 94. There have been instances in which a minority regarded the matter as not clair, which caused the Supreme Court to refer. In Aventis Pasteur, it was the insistence of Lord Rodger that the matter was not clear that caused the reference. He was proven right by the ECJ judgment. $O B v$ Aventis Pasteur SA [2008] UKHL 34, paras 23-25. See also Dermod Patrick O'Brien $v$ Ministry of Justice [2017] UKSC 46, para 20; SSHD v Franco Vomero [2016] UKSC 49, para 27. Fusco 2015, 1535. 
the Dutch administrative court judges and held that the question is 'whether it is a point in relation to which reasonable minds or courts might differ', and whether 'it is a runnable case in the ECJ'; thus, there is no need to refer 'when we are sufficiently confident that we know the answer that the ECJ adopts' ${ }^{91}$ Another judge pointed to the 'slightly imprecise and elusive' nature of the test and noted that it is essentially about 'testing our own confidence' ${ }^{92}$ CILFIT does not imply a guarantee, because if a judge needed a guarantee, he/she would have to refer every single case, since there is never certainty in law. ${ }^{93}$ Given this pragmatic reading, it is perhaps unsurprising that the literature has criticized the UK Supreme Court (and previously the House of Lords) for concluding too easily that a matter is clair and for behaving as if it had the same discretion as the lower courts. ${ }^{94}$ Arnull points to quite a few cases in which the issue of referral was not addressed, even though a reference was possible or even warranted. ${ }^{95}$ This is true, for example, of Zambrano-type cases on social benefits ${ }^{96}$ and unfair terms in consumer contracts. ${ }^{97}$ Particularly debatable are cases in which the Supreme Court reversed the decision of the Court of Appeal on a point of EU law without a reference. ${ }^{98}$ One recent example is $F M X$ Food, concerning time limits for the payment of customs duties, in which the Supreme Court came up with two competing lines of ECJ case law, but argued that the correct interpretation was obvious and thereby reversed the decision of the Court of Appeal. ${ }^{99}$

Judges have been critical of the rigidity of the CILFIT requirements on paper and their application in practice. Some Dutch and especially UK judges have voiced their criticism of CILFIT quite openly. The current president of the UK Supreme Court, Lord Reed, held that it is difficult to apply the acte clair doctrine when the ECJ creatively interprets EU law beyond the intentions of the EU legislature. ${ }^{100}$ Lord Mance also pointed to some practical problems, especially in light of not infrequently unclear ECJ judgments. He noted that an overliteral application would be undesirable given the workload of the

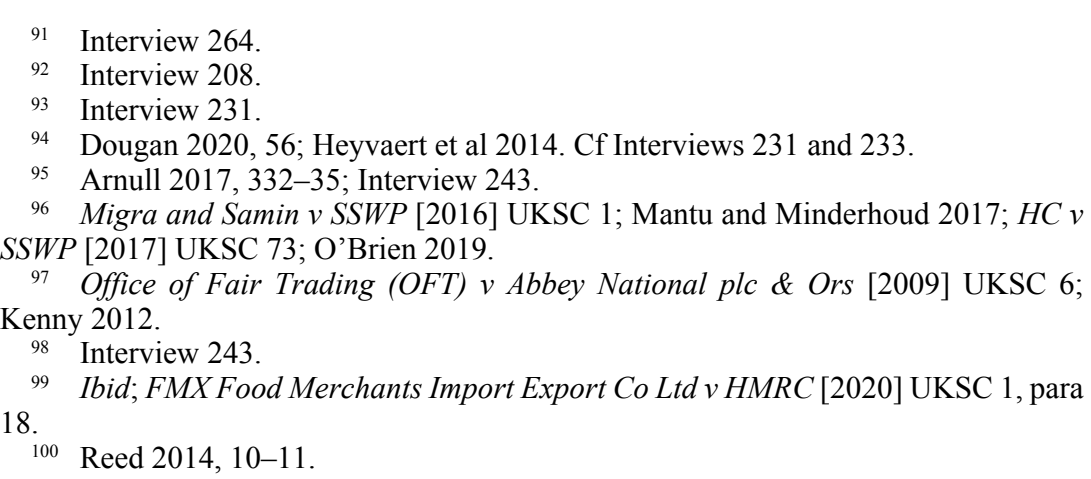


ECJ, which has become even heavier since the expansion of the EU, requiring 'superhuman capacity'. In his view, 'the chimera of unseen language versions or unforeseeable future decisions by other national courts' does not constitute an obligation to refer. He thus disagreed with the argument that there can be no acte clair when courts at different levels or judges within the Supreme Court arrive at different interpretations. ${ }^{101}$ This echoes speeches delivered by former UK AG Jacobs. ${ }^{102}$

The reluctance to refer thus translates into a preference for resolving the dispute on other (national) grounds to avoid a reference. ${ }^{103}$ Article 267 TFEU prescribes that a reference is required where 'a decision on the question is necessary to enable it to give judgment'. Courts and judges, especially in the UK, have emphasized that the specific facts of the case should really necessitate a reference. ${ }^{104}$ Lord Denning acknowledged in Bulmer that an early reference 'might save much time and expense', but noted that all facts must be ascertained first. ${ }^{105}$ Sometimes judges decide not to refer and to wait for a case that lends itself better to referral and allows the court to present the full picture to the ECJ. ${ }^{106}$ Another option to avoid referral is to assume that EU law applies without this being obvious. This happened, for example, in a series of cases concerning the provision of services, in which the Dutch Council of State assumed that the Services Directive was applicable and simply started to review against it. In doing so, it avoided the more fundamental preliminary question raised in 2014 in Trijber and Harmsen as to whether the Services Directive applies at all to internal situations. ${ }^{107}$

The UK courts in particular have applied the test of whether a reference is determinative for resolution of the dispute quite rigorously. ${ }^{108}$ The UK Supreme Court itself held, in response to a written question: 'If, however the

101 Mance 2013a, paras 23-26.

102 Jacobs 2014, 3.

103 Interviews 10, 66, 72, 81, 89, 102, 136, 148, 155, 159, 161 and 162. Eg Ullah, $R$ (on the application of) $v$ SSHD [2017] EWHC 1999 (Admin); Gaswise Ltd v Dublin City Council [2014] IEHC 56, para 70; SFA v Minister for Justice \& Ors [2016] IEHC 222, para 47; Sevenster and Wissels 2016, 90.

104 Interviews 139 and 162; Minister for Justice and Equality $v$ Bailey [2017] IEHC 482, para 44; SSHD v Manjot Singh Dhami EA036232015 [2017] UKAITUR, para 18.

${ }_{105}$ HP Bulmer Ltd \& Anor v J Bollinger SA \& Ors [1974] EWCA Civ 14. Cf VIIV Healthcare UK Ltd v Teva UK Ltd [2015] EWHC 1074 (Ch).

106 Interview 10; Sevenster and Wissels 2016, 91.

107 Interview 44. Eg NL:RVS:2011:BT2130, para 2.6.1; NL:RVS:2014:726, para 29.4 .

108 Interview 231. Eg Asda Stores Ltd v Brierley \& Ors [2019] EWCA Civ 44, para 115; Bancoult, $R$ (on the application of) $v$ The Secretary of State for Foreign and Commonwealth Affairs [2014] EWCA Civ 708, paras 130 and 144. 
unclear point of EU law does not need to be resolved in order to dispose of a case, a reference will not be made.' It pointed to Aspen Underwriting as an example. Article 7(2) of the Brussels Regulation Recast (1215/2012) was not considered by the Supreme Court because it was unnecessary to do so, given that Article 14 applied and disposed of the case. This was despite the fact that Articles 7(1)-(2), and the relationship between them, were not entirely clear. ${ }^{109}$ The Supreme Court justified this approach by pointing to the similar approach of the ECJ in handling references by answering only the question necessary to resolve the dispute and leaving other questions unanswered. ${ }^{110}$ The UK Court of Appeal held in W Nagel that a particular point was not an acte clair, and that although 'it might in other circumstances have been necessary' to refer, the case at hand could be resolved without ruling on this point. ${ }^{111}$ In The London Taxi Corporation it likewise determined that 'these are questions on which, had they been critical to the decision, I would have sought the opinion of the ECJ on a preliminary reference'. ${ }^{12}$ The High Court also refused a reference in Canary Wharf because the questions involved were not 'critical' to its final decision, since they were only 'stepping stones towards resolving a greater question'. ${ }^{113}$

Most judges in the three countries studied shared the view that it is preferable to resolve matters 'with good decency' on the basis of the jurisprudence of the ECJ, especially if there are other cases with 'enough similarities' or 'clear indications'. ${ }^{114}$ The idea is that, from a study of the jurisprudence of the ECJ, a certain line can always be discerned. Some courts - especially the UK courts - are more eager to assume this responsibility and strictly observe the distinction between the interpretation of EU law (for the ECJ) and questions relating to the application of established principles of EU law to the national

109 Aspen Underwriting Ltd \& Ors v Credit Europe Bank NV [2020] UKSC 11; written response 15 April 2020.

110 Eg Case C-603/17 Bosworth EU:C:2019:310; written response 15 April 2020.

111 W Nagel (a Firm) v Pluczenik Diamond Co NV [2018] EWCA Civ 2640, para 86. Cf HMRC v The Open University [2016] EWCA Civ 114, para 114; SSHD v Vassallo [2016] EWCA Civ 13 (Richard LJ); Evans, $R$ (On the application of) $v$ The Information Comrs [2014] EWCA Civ 254.

112 The London Taxi Corporation Ltd (t/a the London Taxi Co) v Frazer-Nash Research Ltd \& Anor [2017] EWCA Civ 1729. Cf Shirley \& Anor, R (on the application of) $v$ The Secretary of State for Housing, Communities and Local Government [2019] EWCA Civ 22, para 63.

113 Canary Wharf (BP4) T1 Ltd \& Ors v European Medicines Agency [2019] EWHC $335(\mathrm{Ch})$, paras 116 and 122 .

114 Interviews 58, 83, 89, 93, 108, 136, 139, 144, 148 and 162; eg BAM PPP PGGM Infrastructure Cooperative UA $v$ National Treasure Management Agency \& Anor [2016] IEHC 546; Maher 2018, 173 and 185. 
legal and factual framework (for national courts). ${ }^{115} \mathrm{UK}$ courts have acted in line with AG Jacobs' call for 'self-restraint' in his Opinion in Wiener. He cautioned against national courts referring for 'further clarification' when the facts of the case differ only slightly from those in which the ECJ has already answered similar questions. ${ }^{116}$ He noted that:

in particular in many technical fields, such as customs and value added tax, national courts and tribunals are able to extrapolate from the principles developed in this Court's case law. Experience has shown that that case law now provides sufficient guidance to enable national courts and tribunals - and in particular specialised courts and tribunals - to decide many cases for themselves without the need for a reference. ${ }^{117}$

Lord Reed underscored that there is no need to refer when it 'is simply a matter of applying established principles, even they are expressed in a way which leaves room for argument as to their application to the facts'. ${ }^{118}$ The UK Supreme Court, for example, justified its conclusion in several cases that no reference was necessary since the decision was an application of established ECJ jurisprudence. The court based this finding on the fact that the ECJ had answered similar questions of the Court of Appeal without an AG Opinion. ${ }^{119}$ The UK lower courts are also generally quite quick to conclude that it is just a matter of applying (established) principles to the facts (see section 3.3). ${ }^{120} \mathrm{On}$ quite a few occasions, a higher court decided to refer at a later stage, despite the confidence of the lower courts. ${ }^{121}$

One former UK Supreme Court judge noted that not all courts in the EU maintain this distinction between application and interpretation, and hence tend to 'over-refer'. ${ }^{122}$ These courts 'look at the ECJ as if it is their godfather'

115 Cf BVerfG 1 BvR 276/17 and 1 BvR 16/13; Burchardt 2020, 16.

116 Case C-338/95 Wiener EU:C:1997:352, para 15.

117 Ibid, para 61.

118 Reed 2014, 14.

119 HMRC v Frank A Smart and Son Ltd (Scotland) [2019] UKSC 39, paras 59 and 64; Cf Walton v Scottish Ministers [2012] UKSC 44, paras 31 and 71; Office of Fair Trading $v$ Abbey National plc \& Ors [2009] UKSC 6, para 50; HS2 Action Alliance Ltd, $R$ (on the application of) $v$ The Secretary of State for Transport \& Anor [2014] UKSC 3, paras 53-55.

${ }_{120}$ Coal Staff Superannuation Scheme Trustees Ltd v HMRC [2017] UKUT 137 (TCC), paras 36-37; Virgin Media Ltd \& Anor v HMRC [2020] UKFTT 30 (TC), para 431.

121 Davis \& Ors, $R$ (on the application of) v SSHD \& Ors [2015] EWHC 2092 (Admin), para 110; Mercedes-Benz Financial Services UK Ltd v HRMC [2014] UKUT 200 (TCC).

122 Interview 264. 
and 'as if they are still growing up'. By contrast, the UK Supreme Court feels that it is its role to apply EU law by itself. It considers that it is reasonably good at this, and thus that only the really 'difficult cases' need to be referred. ${ }^{123}$ Two UK barristers noted that although the UK Supreme Court is sometimes 'cheating not to refer', it approaches its obligation to refer and to CILFIT in a 'fairly straight' way: '[I]f they need to refer, they do it." ${ }^{124}$ One barrister likewise noted that the references made by courts in other Member States explore the boundaries between interpretation and application, and frequently deal with proportionality questions that are for national courts themselves to handle. He/she observed that UK references are 'quite tough', and noted that the UK courts invest more time than other courts in the order for reference; while Italian references, for instance, are often 'crap' and should not have been made. ${ }^{125}$

One particular UK trait that explains why the UK courts, including the lower courts (section 3.3), have assumed the responsibility of applying established principles to new cases is their innate confidence in themselves. One Supreme Court judge noted:

$[\mathrm{W}] \mathrm{e}$ do not surrender our own responsibility...

[W]e are quite a confident jurisdiction and we became competent European lawyers. We make up our own mind and we have a clear view of which we think that the ECJ would endorse. ${ }^{126}$

The UK courts are especially confident in the area of private international and commercial law, where the prevailing view is that the UK sets an example that Luxembourg can follow. This also relates to the ECJ's perceived lack of expertise in the area of (international) private law, which can translate into errors when applying common law doctrines. ${ }^{127}$ There has been dissatisfaction

$123 \mathrm{Ibid}$; 'We fulfilled our obligation to the letter' and applied CILFIT 'fairly rigorously', Interview 208. The Supreme Court held in April 2020:

The Supreme Court's case law shows that it does not decline to make references just because it could be unhelpful or inconvenient to make a reference. If the CILFIT criteria require a reference, the Supreme Court will be bound to make a reference. If the parties share a view of EU law which the Supreme Court considers is not acte clair, and if decision of the point is necessary for the disposal of the appeal, the Supreme Court will still make a reference.

Written response 15 April 2020.

124 Interviews 231 and 243.

125 Interview 243. Only 42 per cent of the Italian references resulted in a ECJ judgment, while this figure is 61 per cent for all EU Member States in the period 1961-2006, Vink et al 2009, 7.

126 Interview 264.

127 Mance 2011; para 32; Arnull 2010, 81; Harris 2008, 375. 
with several ECJ judgments in this area. Hartley even pointed to a 'crisis of confidence among English lawyers' and a view that the ECJ 'cannot be trusted to give reasonable decisions' in this field. ${ }^{128}$ One former UK Supreme Court judge mentioned that initial conscientious references in relation to the Brussels I Regulation (44/2001) led to judgments that 'upset' the UK courts, but that were subsequently corrected in the EU legislation via the Brussels Recast Regulation. One example is the West Tankers case, which concerned anti-suit injunctions against firms that wrongfully start court proceedings in other Member States on the grounds that such proceedings would be contrary to an arbitration agreement. The House of Lords put forward quite a firm view in its reference, with the message 'please permit this under the Brussels Regulation'. ${ }^{129}$ The ECJ nonetheless held that an order that hinders a person from commencing or continuing proceedings before the courts of another Member State is incompatible with the Regulation. This was considered an unwanted outcome, depriving 'us' of an important weapon to support English arbitration. ${ }^{130}$

One judge likewise attributed the relatively fewer UK references to the hypothesis that the UK courts are better at analysing ECJ case law and finding an answer on that basis. He/she attributed this to the superior training and experience of UK judges, as well as the high level of the bar and the fact that barristers often provide a full analysis and statement of the law. ${ }^{131}$ The prevailing view is that Luxembourg would reach more or less the same conclusion as the UK Supreme Court by examining the case law. ${ }^{132}$ 'Why would one need to refer when this can be done ourselves?' was also the argument of Lord Brown, who added: 'It seems to me unrealistic to suppose that the Court of Justice would feel able to provide any greater or different assistance than we have here sought to give. ${ }^{133}$ Implicit in this account is also the idea that a reference is a 'lazy' gesture of a national court, whereby difficulties are outsourced to another institution and the court does not fulfil its own responsibility to investigate. One example is the Aimia case, which Lord Reed maintained could have been decided by the House of Lords without a referral had it spent more time reflecting on possible answers to the questions. ${ }^{134}$ As will be discussed later,

\footnotetext{
128 Hartley 2006, 183.

129 Case C-185/07 West Tankers EU:C:2009:69. Cf Arnull 2010, 82; Harris 2008, 369 and 383.

130 Interview 264.

131 Interview 208.

132 Ibid.

133 Morge v Hampshire County Council [2011] UKSC 2, para 25. Cf The Trustees of the BT Pension Scheme v HMRC [2013] UKUT 105 (TCC), para 420.

134 Reed 2014, 13.
} 
there are several recent decisions in which the Supreme Court determined the scope and effect of EU law itself, such as HS2 and Stott v Thomas Cook (see Chapter 4, section 2). ${ }^{135}$

A UK barrister confirmed this self-image of UK judges. He noted that the House of Lords and the Supreme Court have been more 'adventurous' than other EU courts in their dealings with EU law and have referred only the more 'extreme' cases to the ECJ. This barrister also highlighted the 'intellectual confidence' of individual judges in interpreting what EU law means, without voicing a strong normative opinion about it. The prevailing attitude is that 'we can understand EU law as well as the ECJ'. He/she observed that judges such as Lord Reed and Lord Mance have gained in confidence over the last decade. $\mathrm{He} / \mathrm{she}$ further noted that judges with an academic background, such as Lord Reed, are generally more confident to argue that EU law requires a particular interpretation without a reference. Something similar was said about Lord Mance, a fluent German speaker who previously spent time practising at a German law firm. The barrister went on to observe that this intellectual confidence can be regarded as English arrogance, because English judges regard themselves as the intellectual elite. He/she would not be surprised if there were a view among Supreme Court judges that the judges appointed to the ECJ 'are not really up to much' and are not necessarily the top people in their countries - not least because of the political nature of the appointment process. ${ }^{136}$ It is perhaps unsurprising that judges in common law countries are more self-conscious, given their important law-making roles compared to the civil law 'bouche de la loi' judges. ${ }^{137}$

Summing up, this section has revealed that some highest courts have adopted a pragmatic reading of CILFIT. One reason behind the UK Supreme Court's approach is its confidence in its own ability to interpret EU law. This section has discussed this without passing judgement on the practice. However, one normative question is whether the practice is problematic from an EU law point of view. The concluding chapter of this book will present some reflections on this question.

\subsubsection{Lower courts: discretion and self-restraint}

Lower courts have been most explicit in their judgments about their reluctance to refer. Quite a number of UK judgments refer approvingly to the Opinion of former AG Jacobs in Wiener that a 'measure of self-restraint' is required from

135 Ibid, 14.

136 Interview 211.

137 Hornuf and Voigt 2015, 295. 
national courts. ${ }^{138}$ Irish High Court Judge Simons referred to the 'principle of judicial self-restraint' in his decision to refer ${ }^{139}$ Although most Irish lower court judges are in principle not opposed to referring at an early stage, they emphasized that they refer only if this will directly affect the outcome of the case. ${ }^{140}$ For example, one Irish judge stated, 'We do not look for trouble', and argued that courts should not immediately 'run out to Luxembourg' and 'thrash out a reference'. ${ }^{141}$ Judges also prefer to make their own judgments. ${ }^{142}$ For example, one Dutch judge stated that it might be preferable to make a mistake in one case than to engage in unnecessary judicializing and refer in case of the slightest doubt. ${ }^{143}$

The Dutch lower courts, and to a lesser extent the UK courts, were particularly keen to emphasize their discretion to refer. The judges interviewed clearly indicated that the TFEU mandates them to decide themselves, even where there is doubt about the interpretation of EU law. ${ }^{144}$ One judge admitted that he/she would have referred a particular case had he/she been the judge of final instance. ${ }^{145}$ This reluctance is informed by judges' views of their positions in the judicial hierarchy and inclination to leave references to the highest courts (see Chapter 3, section 2.1). The position of the Dutch lower courts stands in sharp contrast to that of the Irish lower courts, which feel de facto obliged to refer (section 2.3) and frequently mentioned the advantages of an early, 'better-sooner-than-later' referral. ${ }^{146}$ Two examples illustrate the approach of the Dutch lower courts. In an IP case about copyright licence fees, the Amsterdam Court of Appeal held that questions were not obvious because the law at issue had been amended. It nonetheless pointed out that the case dealt with a relatively limited period in the past, and that the material interest in referring was therefore limited. ${ }^{147}$ A second example is Lemnis Lighting, which concerned the customs classification of light-emitting diode bulbs. The Dutch lower court had 'enormous' doubts because the Combined Nomenclature

138 Case C-338/95 Wiener EU:C:1997:352; Tan v Choy [2014] EWCA Civ 251; Littlewoods Retail Ltd \& Ors v HMRC [2014] EWHC 868 (Ch), para 114.

139 Friends of the Irish Environment Ltd v Minister for Communications, Climate Action and Environment \& Ors [2019] IEHC 685, para 11. Cf Sweetman v Environmental Protection Agency \& Anor [2019] IEHC 81, para 93.

140 Interviews 102, 108, 139, 148, 161, 166 and 191.

141 Interview 159.

142 Interviews 16, 22, 39, 49, 51, 65, 74, 83 and 93.

143 Interviews 22, 51 and 58.

144 Interviews 39, 49 and 51. Eg Stryker NL:RBNHO:2016:3626.

145 Interview 51.

146 Interviews 144, 171, 174 and 187; Recorded Artists Actors Performers Ltd v Phonographic Performance (Ireland) Ltd [2019] IEHC 3, para 88.

147 Ziggo Services, NL:GHAMS:2016:4183, ro 3.8. 
was silent on this new technology. A final hearing discussing this matter lasted a day. ${ }^{148}$ In the end, there was a reasonable solution to which all judges involved agreed and which was thought to be the only possible classification. The Tax Chamber of the Dutch Supreme Court nonetheless decided to refer. The lower court's interpretation turned out to be correct in retrospect, because the ECJ eventually arrived at the same classification as the lower court. ${ }^{149}$

It is more difficult to sketch a general picture of the approach of those UK courts that are not obliged to refer. Sometimes they are as reluctant to do so as the Dutch lower courts. Other times, those courts - especially the intermediate appellate courts and specialized tribunals - reason in a similar way to their Irish counterparts and apply CILFIT rather strictly. This explains why these courts have traditionally made a big deal of UK references. ${ }^{150}$ The dichotomy reflects the discussion in the case law of the UK courts as to the position of the lower courts. Earlier, we saw that Sir Bingham limited the complete discretion of lower courts in ex parte Else (section 2.3). Lord Denning took the opposite stance and famously held in Bulmer in 1974 - very much in line with the general practice of the Dutch lower courts - that, except for the House of Lords, the UK courts have 'complete discretion'. A judge:

need not refer it to the court at Luxembourg unless he wishes. He can say: 'It will be too costly', or 'it will take too long to get an answer', or 'I am well able to decide it myself.' If he does decide it himself, the European court cannot interfere. ${ }^{151}$

Lord Denning's discouragement is seen as an important reason why many UK (lower) courts have been reluctant to refer over the years. ${ }^{152}$ Bulmer is still relied upon by courts in their decisions and especially those deciding not to refer. ${ }^{153}$ Lord Justice Lewison held:

if a national court is sure enough of its own interpretation to take the responsibility (and possibly the blame) for resolving a point of law without the assistance of the Court of Justice, it ought to be legally entitled to do so. ${ }^{154}$

\footnotetext{
148 Interview 55.

149 C-600/15 Lemnis Lighting EU:C:2016:937.

150 The Gibraltar Betting and Gaming Association Ltd and $R$ (on the application of) $v$ HMRC \& Ors [2015] EWHC 1863 (Admin), para 10; Arden 2010, 11; Dyevre et al 2019, 11 .

${ }_{151}$ HP Bulmer Ltd \& Anor v J Bollinger SA \& Ors [1974] EWCA Civ 14.

152 Craig 1998, 200-05; Arnull 2010, 59; Wind et al 2009, 77.

153 Eg Abbotsley Ltd \& Ors (t/a Cambridge Meridian Golf Club) v HMRC [2015] UKFTT 662 (TC), para 139.

${ }_{154}$ He relied on C-197/14 X and Van Dijk EU:C:2015:564 in O'Brien v Ministry of Justice [2015] EWCA Civ 1000.
} 
Many UK judgments emphasize this discretion, reducing the question to refer to an issue of appropriateness. ${ }^{155}$

The (specialized) lower UK courts, just like the UK Supreme Court, are quite confident in their ability to interpret EU law themselves. The Court of Appeal, the High Court ${ }^{156}$ and tribunals ${ }^{157}$ are confident in declaring a question to be clair - even in cases which are subsequently referred by the Court of Appeal or the Supreme Court. The UK lower courts refer more frequently than the Dutch lower courts, which prefer the 'easy route' of concluding that an answer is not necessary or which stress their discretion to refer. Hence, it sometimes happens that the Court of Appeal concludes rather confidently that the issue is clear and is based, for example, on 'established principles', but the Supreme Court nonetheless decides to refer. ${ }^{158}$ One example is the statement of Lord Justice Laws that there was no 'force whatever' to seek a preliminary reference on the term 'family member' in relation to a child's guardianship under the Algerian kafala system. He was later proven wrong about this term by the Grand Chamber judgment following the UK Supreme Court's reference in $S M .{ }^{159}$ One barrister explained that it is easier for a court to say that a matter is clair than to leave it to the higher court and give permission to appeal, not least because appeal is 'a long and hard road'. It is considered institutionally inappropriate and questionable from the perspective of legal certainty to say, as the Dutch lower courts have done, that it is an uncertain point of law and just leave it at that. ${ }^{160}$

155 Eg Simonis, $R$ (on the application of) v Arts Council England (Rev 2) [2020] EWCA Civ 374, para 111; Brownlie v Four Seasons Holdings Inc [2015] EWCA Civ 665.

156 Eg United Biscuits (Pension Trustees) Ltd v HMRC [2017] EWHC 2895 (Ch) (later referred in Case C-235/19 United Biscuits (Pensions Trustees) and United Biscuits Pension Investments EU:C:2020:801); Glaxo Wellcome UK Ltd (t/a Allen and Hanburys) \& Anor v Sandoz Ltd [2016] EWHC 1537 (Ch), para 75; Safeway Ltd $v$ Newton \& Anor [2016] EWHC 377 (Ch) (later referred in Case C-171/18 Safeway EU:C:2019:839); Stunt v Associated Newspapers Ltd [2017] EWHC 695 (QB) (later referred in Case C-687/18 Associated Newspapers EU:C:2019:988).

157 BAT Industries plc \& Ors v HMRC [2017] UKFTT 558 (TC), para 259.

158 Volkswagen Financial Services (UK) Ltd v HMRC [2015] EWCA Civ 832 (later referred in Case C-153/17 Volkswagen Financial Services (UK) EU:C:2018:845); O'Brien v Ministry of Justice [2015] EWCA Civ 1000 (later referred in Case C-432/17 O'Brien EU:C:2018:879); The Association of Independent Meat Suppliers \& Anor, $R$ (on the application of) $v$ The Food Standards Agency [2017] EWCA Civ 431 (later referred in Case C-579/19 Food Standards Agency).

159 SM (Algeria) v Entry Clearance Officer, UK Visa Section [2015] EWCA Civ 1109.

160 Interview 112. 


\subsubsection{Importance of the question}

Judges in all three countries, and especially lower court judges, take into account the importance of the question of EU law at issue. ${ }^{161} \mathrm{~A}$ reference is more likely where the question plays a role in a considerable number of cases or where the financial or societal consequences are substantive. ${ }^{162}$ Particularly illustrative is the guidance in AG Jacobs's Opinion in Wiener, which has been relied upon frequently by the UK courts:

a reference will be most appropriate where the question is one of general importance and where the ruling is likely to promote the uniform application of the law throughout the European Union. A reference will be least appropriate where there is an established body of case law which could readily be transposed to the facts of the instant case; or where the question turns on a narrow point considered in the light of a very specific set of facts and the ruling is unlikely to have any application beyond the instant case. ${ }^{163}$

High Court Judge Mostyn justified his first-ever reference by pointing to the 'potential ramifications' of a particular interpretation that were 'potentially quite wide-ranging'. ${ }^{164}$ Irish judges have also noted that the question should be more than just a local dispute, but of pan-European importance. ${ }^{165}$ In its reference in $M M$ the Irish Supreme Court mentioned the 'huge implications for current administrative practice' with regard to the system of subsidiary protection and noted that the outcome in this case would affect many other pending cases. ${ }^{166}$ A reference has the advantage of resolving a particular legal question without further litigation in many cases. ${ }^{167}$ Similar considerations guided the reference of the Dutch Council of State in $A, B, C$, on the review of the credibility of the declared sexual orientation of an asylum seeker. ${ }^{168}$ The UK courts in particular have frequently referred to the broad impact and 'general public

161 Interviews 8, 16, 39 and 93.

162 Interviews 8, 22, 55, 65 and 93; De Staat der Nederlanden $v$ Warner-Lambert Company LLC NL:GHDHA:2017:567, para 4.2; Veevoederbedrijf Alpuro BV NL: GHARL:2016:3097, para 9.5.

163 Case C-338/95 Wiener EU:C:1997:352; Trinity Mirror plc $v$ Customs and Excise Comrs [2001] EWCA Civ 65; Canary Wharf (BP4) T1 Ltd \& Ors v European Medicines Agency [2019] EWHC 335 (Ch), para 116.

$164 S v S$ [2014] EWHC 3613 (Fam), para 57.

165 Interviews 187 and 191. Eg Schrems v Data Protection Comr [2014] IEHC 310 (Hogan J), para 71 .

${ }_{166}$ MM v Minister for Justice, Equality \& Law Reform \& Ors [2011] IEHC 547

(Hogan J), para 32; Mahmood \& Anor v Minister for Justice [2018] IECA 3 (Hogan J), para 61.

${ }_{167}$ HID (A minor) \& Anor v Refugee Applications Comr [2013] IEHC 146 (Cooke J), para 32 .

168 Joined Cases C-148/13 until C-150/13 A, B, C EU:C:2014:2406. 
importance' of a legal question, as well as the number of pending cases to which it relates, as additional considerations. ${ }^{169}$ As will be discussed in Chapter 4 , section 3, judges sometimes refer cases involving significant interests out of prudence. One example is the reference of the Trade and Industry Appeals Tribunal in IMC Securities, about the legality of a fine for price manipulation. The Tribunal considered the issue to be relatively clair, which is also reflected in the very concise judgment of the ECJ. However, a reference was nonetheless considered desirable because of the importance of the principle of legal certainty. ${ }^{170}$

Issues of minor importance, one-off cases and cases of 'semantic concern' are more easily decided without a referral. ${ }^{171}$ Several Irish court decisions not to refer mention, for example, the 'theoretical interest' or the fact that the point of law is not 'one of exceptional importance'. ${ }^{172}$ The same holds true for an issue that relates to legislation which has already been revised or which will be revised in the near future. Questions of academic or historic interest are avoided where a measure or law is repealed or replaced before an ECJ judgment is due. ${ }^{173} \mathrm{~A}$ reference is more likely if a legal mechanism will continue to be relevant for another six years. ${ }^{174}$ The Trade and Industry Appeals Tribunal was reluctant to refer a dispute concerning telephone call termination rates that would be valid for a period of three years only. ${ }^{175}$ One exception to this reluctance to refer one-off or outdated cases is important matters of principle. ${ }^{176}$ The Dutch Council of State, for instance, referred a case concerning registration certificates that affected only one person and had no further consequences for other cases. It concerned a single appellant who had never been able to drive

169 HMRC v Brockenhurst College [2015] EWCA Civ 1196, para 28; Sky plc \& Ors v Skykick UK Ltd \& Anor [2018] EWHC 155 (Ch), para 357; HMRC v HD [2018] UKUT 148 (AAC), para 40; East Sussex County Council v IC [2014] UKFTT EA_2013_0037 (GRC), para 1.

${ }_{170} I M \bar{C}$ Securities BVv Stichting Financiële Markten NL:CBB:2009:BK2641; Case C-445/09 IMC Securities BV EU:C:2011:459; Interviews 31 and 69.

171 Canary Wharf (BP4) T1 Ltd \& Ors v European Medicines Agency [2019] EWHC 335 (Ch), para 120; Shields \& Sons Partnership v Revenue \& Customs [2016] UKUT 142 (TCC), para 37; Lim v Malaysia [2013] UKUT 437 (IAC), para 32.

172 SFA v Minister for Justice \& Ors [2016] IEHC 222, para 51; A.A. (Nigeria) v Minister for Justice, Equality and Law Reforms \& Ors [2015] IEHC 210, para 12.

173 Dacis \& Ors $R$ (on the application of) v SSHD \& Ors [2015] EWHC 2092 (Admin), para 113; Coal Staff Superannuation Scheme Trustees Ltd v HMRC [2017] UKUT 137 (TCC), paras 34-35.

${ }_{174}$ Merck Canada Inc v Sigma Pharmaceuticals plc [2013] EWCA Civ 326, para 100.

175 Interview 77.

176 Interviews 12, 18, 24, 32, 44 and 66; Sevenster 2011, 301. 
in his vintage car; but underlying this factual situation was an important matter of principle. ${ }^{177}$

Interestingly, the UK (lower) courts have been particularly concerned about the importance of questions from the perspective of the uniformity of EU law and the need for a level playing field for businesses and consumers. ${ }^{178}$ This does not seem to be driven by a desire to contribute to the development of EU law, as was discussed in relation to the Dutch and Irish Supreme Courts (section 2.1), but rather by an economic and business logic. ${ }^{179}$ In Nutricia, the High Court pointed to 'other reasons' than (legal) reasons - namely, the 'importance of the issues and the desirability of a common approach being applied across the EU which will afford greater and more consistent guidance both to Competent Authorities and to producers'. It pointed to the differences across Member States and to the negative effects for legal certainty and the integrity of the internal market. ${ }^{180}$ Similar reasoning was employed in cases relating to supplementary protection certificates (SPCs) for medicinal products and the need for an authoritative ruling of the ECJ to avoid divergent interpretations of national courts. ${ }^{181}$ The Upper Tribunal also underlined in its reference the need for a uniform interpretation of VAT rules with respect to the meaning of 'sport' and determined that 'it would in our view be of little value for us to add a further domestic view to the mix'. ${ }^{182}$ Aside from business and tax law cases, the UK courts have also underlined the need for a uniform interpretation and an authoritative judgment of the ECJ in the area of family law. ${ }^{183}$

In sum, the importance of the issue matters. There is, however, a tipping point where the issue becomes so important, and the number of affected cases so great, that a reference is less likely, as the following section will outline.

177 Interview 72; RDW NL:RVS:2017:1370.

178 European Federation for Cosmetic Ingredients, $R$ (on the application of) $v$ The Secretary of State for Business, Innovation and Skills \& Ors [2014] EWHC 4222 (Admin), para 25; The Gibraltar Betting and Gaming Association Ltd, R (on the application of) v HMRC [2015] EWHC 1863 (Admin), paras 13-14.

179 Eli Lilly and Co $v$ Genentech, Inc [2019] EWHC 388 (Pat), paras 48 and 50.

180 Nutricia Ltd, $R$ (on the application of) $v$ The Secretary of State for Health [2015] EWHC 2285 (Admin), paras 20 and 214.

181 Merck Sharp and Dohme Corporation v Comptroller-General of Patents, Designs And Trade Marks [2016] EWHC 1896 (Pat), para 49; Beverly Hills Teddy Bear Co v PMS International Group plc [2019] EWHC 2419 (IPEC), para 60.

182 The English Bridge Union Ltd v HMRC [2015] UKUT 401 (TCC), paras 17 and 23. Cf Healthspan Ltd v HMRC [2018] UKFTT 241 (TC), para 267.

183 Healthspan Ltd v HMRC [2018] UKFTT 241 (TC), MS v PS [2016] EWHC 88 (Fam), paras 6 and 42. 


\subsubsection{Delays and consequences for the parties}

It is no surprise that in deciding whether (not) to refer, courts - and especially lower courts - consider the consequences of a reference both for the specific case and the parties involved, and for other related cases. Some of the judges interviewed suggested that if the procedure lasted only one or three months, they would be quicker to make references. ${ }^{184}$

This notwithstanding, delay is in fact a more limited consideration for the courts than one might possibly expect. Relatively few Dutch ${ }^{185}$ and Irish judgments explicitly mention delay; although the UK courts seem to attach more importance to this. ${ }^{186} \mathrm{~A}$ good illustration is the UK Court of Appeal judgment in Brownlie, in which Lady Justice Arden recognized that the questions were 'clearly not acte clair', but noted that a reference 'would involve considerable delay and commit the parties irreversibly to that route without a clear result at this time to this appeal' ${ }^{187}$ (Former) UK Supreme Court judges, such as Lord Mance and Lord Walker, have openly admitted that the time and costs of a reference are taken into consideration. ${ }^{188}$ The UK Supreme Court considered that the public interest in resolving the case quickly was more important than the need to refer in Abbey National, which concerned the fairness of bank charges. ${ }^{189}$ Another example is the child custody case of $N$ (children). Lady Hale noted that the question as to whether Article 15 is capable of applying to public law proceedings was not an acte clair. The Supreme Court nonetheless proceeded on the assumption that Article 15 applies to public law proceedings because 'these proceedings have already taken far too long' and the children's 'best interests demand that their future should be decided as soon as possible' ${ }^{190}$ Likewise, the Supreme Court resolved the child abduction case $A$ (children), in the words of Arnull, to avoid a reference. It found that the matter was not clair with respect to the 'habitual residence' point, but avoided that issue by remitting the case to the High Court as 'a matter of urgency' in order to exercise its inherent jurisdiction. ${ }^{191}$ Another example is the private international

184 Interviews 89, 106, 108, 136 and 181; Sevenster 2011, 301.

185 One exception is NL:RVS:2011:BR3771, para 2.8.4; Sevenster and Wissels 2016, 92.

186 Jaspers (Treburley) Ltd \& Ors, $R$ (on the application of) $v$ Food Standards Agency [2013] EWHC 1788 (Admin).

187 B (A Child) [2013] EWCA Civ 1434, paras 24 and 83.

188 Mance 2013a, para 11; Office of Fair Trading $v$ Abbey National plc \& Ors [2009] UKSC 6 (Lord Walker), para 48.

189 Office of Fair Trading $v$ Abbey National plc \& Ors [2009] UKSC 6 (Lord Walker), para 48.

190 Re N (Children) [2016] UKSC 15 (Hale), paras 54-55; Arnull 2017; Interview 231.

191 A (Children) Re (Rev 1) [2013] UKSC 60; Arnull 2017. 
law case Alexandros Tre, which dealt with whether legal proceedings in the UK should be stayed in favour of proceedings in Greece involving the same cause of action in the light of Articles 27 and 28 of the Brussels I Regulation (44/2001). Lord Clarke held that the questions in relation to Article 27 were not an acte clair and noted that a reference was required if the appellants maintained their particular claims. ${ }^{192}$ The UK Supreme Court gave the parties the option to drop that particular point because it was conscious that otherwise a relatively small part of the case would have to go off to Luxembourg, with consequent delay and costs. ${ }^{193}$

The extent to which delay is taken into consideration depends on the legal area at issue. Delay plays a bigger role in planning cases, where it has adverse (economic) consequences for companies. ${ }^{194}$ The same holds true for family law cases involving child custody and foster cases. ${ }^{195}$ Irish judges expressed a reluctance to refer when someone is not in custody and the case cannot benefit from treatment via the procedure préjudicielle d'urgence (PPU). ${ }^{196} \mathrm{In}$ one case the UK High Court held that even a PPU reference would be 'intolerable' and contrary to 'best interests', since the child had already been in foster care for three years. ${ }^{197}$

The role of delay in decisions not to refer should not be overstated. The Irish and Dutch judges interviewed rarely mentioned delay as a reason not to refer. ${ }^{198}$ Several Irish appellate court judges vehemently rejected the idea that delay was a factor that influenced their decision - not least because Irish courts experience significant delays with or without referral. ${ }^{199}$ They stated that delays are inevitable and can happen at any stage. ${ }^{200}$ One judge observed, for instance: 'That's the way it is. So be it.' 201 Some noted that the delay in Luxembourg is short in comparison to the delays that can arise in Irish legal proceedings. It can two years (or more) to get a hearing date at the Court of Appeal, which means that the Luxembourg route can be faster. ${ }^{202}$ Dutch Tax Chamber judges emphasized that the explicit consideration of delay does not fit within the

192 In the matter of 'The Alexandros T' [2013] UKSC 70, para 72.

193 Interview 264.

194 Eg Garner, $R$ (on the application of) v Elmbridge Borough Council \& Ors [2010]

EWCA Civ 1006; Interviews 5, 10, 69, 77 and 91.

195 London Borough of Lambeth v JO \& Ors [2014] EWHC 3597 (Fam).

196 Interviews 102,113, 148 and 162.

197 The Child and Family Agency (Ireland) $v$ M \& Ors [2018] EWHC 1581 (Fam).

198 Interviews 49 and 93.

199 Interviews 105, 136, 144, 146, 159, 166, 187 and 191.

200 Interviews 102, 144 and 159.

201 Interview 159. Cf Interview 191; MA v The International Protection Appeals Tribunal \& Ors [2017] IEHC 677 (Humphreys J), para 141.

202 Interviews 108 and 153. 
framework of Article 267 TFEU. They also held that in many cases, there is no rush at all - either because of a deferral of payment or because of an ex post claim. ${ }^{203}$ Without giving the impression that processing times are unimportant, one interviewee stated: '[H]ere we have all the time in the world.' ${ }^{204}$ It was also stated that the turnaround time in Luxembourg is not particularly long. ${ }^{205}$ Even the UK Supreme Court does not shy away from referring a second (or even third) time (see Chapter 7, section 4). Prolonged litigation did not rule out a second reference in Aventis, even though Lord Hoffmann considered it 'particularly unfortunate' for the claimant. ${ }^{206}$ Another example of a reference in which a delay was considered far from ideal is O'Brien, which concerned pensions for part-time judges. A reference was eventually made, even though the issue needed to be resolved quickly because some judges perhaps would not live long enough to see the result. ${ }^{207}$ These examples indicate that delay seems to matter less at the Supreme Court stage in all three countries. ${ }^{208}$

Delays obviously matter more in summary or interlocutory proceedings. Judges in all three countries are reluctant to refer in interlocutory proceedings because of the required swiftness of a (provisional) judicial decision. ${ }^{209}$ EU law affords them discretion to do so, because the highest courts are not obliged to refer in summary proceedings. ${ }^{210}$ There is thus considerable room for pragmatic considerations. In interviews, Irish High Court judges suggested that a reference would be 'premature' and 'more appropriate for consideration at the substantive trial' ${ }^{211}$ While urgency is often absent in interlocutory proceedings before the Supreme Court, the Dutch judges interviewed indicated that there should still be 'something special' about a case before a reference is made. ${ }^{212}$

203 Interviews 15 and 78.

204 Ibid.

205 Interview 30.

206 OB v Aventis Pasteur SA [2008] UKHL 34.

207 Interview 208.

208 One former Supreme Court judge (208) also noted that the delay does not obstruct a reference if it is not clear ('then it has to go'). Cf Interviews 231 and 264. The current Supreme Court subscribed to this logic in its written response by holding that it does not decline to make references just because it is 'inconvenient'. Written response 15 April 2020.

209 Eg Connexxion Taxi Services NL:GHDHA:2013:3723, para 3.4; Interviews 8, 14 and 29; Enterprise Holding Inc v Europcar Group UK Ltd \& Anor [2015] EWHC 300 (Ch), para 15. However, see De Staat der Nederlanden $v$ Warner-Lambert Company LLC NL:GHDHA:2017:567, para 4.3.

210 Joined Cases 35/82 and 36/82 Morson EU:C:1982:368, paras 8 and 9.

211 Dowling \& Ors $v$ Cook \& Ors [2013] IEHC 129, para 49; Fitzpatrick \& Anor $v$ Minister for Agriculture, Food and the Marine \& Anor [2018] IEHC 77, para 88. Cf Dowling \& Ors $v$ Minister for Finance [2013] IESC 58 (Fennelly J), paras 64 and 66.

212 Interviews 27, 45, 48, 59 and 87. 
Civil Chamber judges, for instance, felt more compelled to refer where a case concerned a question on which there is very little ECJ jurisprudence or an area in which few cases reach the Supreme Court. ${ }^{213}$ One example of the latter is procurement law: the referral in Connexxion was based on the idea that 'we have to grab the chance', as such cases rarely come before the ECJ. ${ }^{214}$ By contrast, where the importance of the question is of limited practical relevance, the Civil Chamber is less eager to refer and 'dares' to decide itself. ${ }^{215}$ The Civil Chamber also pays more attention to the wishes of the parties in summary proceedings and tends not to refer if the parties do not ask for or do not want a reference. An additional reason for the reference in Synthon was that both parties urged the Supreme Court to refer. ${ }^{216}$

Judges stated that they also consider the position of the affected person(s) and assess whether a reference would have negative consequences for the parties, including in terms of the costs involved. ${ }^{217}$ If the parties - and especially the party that is likely to win - would be exposed to high costs as a result of the reference, it is even more important that it concerns a decisive point which could overturn the case. ${ }^{218}$ Some Irish judges acknowledged that the consequences are given more weight where the parties are opposed to a referral. $^{219}$ This is even more relevant because the legal aid system in Ireland is considered to be limited. ${ }^{220}$ One Irish judge observed that the court is conscious that where a person is funding the litigation himself or herself, a reference would add to the cost burden. ${ }^{221}$ Another Irish judge likewise noted that if the parties could not afford a referral or did not want a referral, then he/she would not refer. ${ }^{222}$ By contrast, it was easier for the Dutch Council of State to refer Somvao. The question in this case was whether the state secretary of justice was able to alter and recover - to the detriment of the beneficiary, Somvao (part) of the grant awarded from the European Refugee Fund in the absence of

213 Interviews 41, 59, 75 and 87.

214 Connexxion Taxi Services NL:HR:2015:757 (Case C-171/15 Connexxion Taxi Services EU:C:2016:948); Interviews 27, 48, 59 and 87.

215 Interviews 27 and 75; Becton v Braun NL:HR:2018:721, para 3.3.7.

216 Synthon v Astellas Pharma Inc NL:HR:2016:2643 (Case C-644/16 Synthon EU: C:2018:61); Interviews 27, 75 and 87.

217 Interviews 14, 22, 32, 35, 91 and 93; Maher 2018, 192.

218 Interview 27.

219 Interviews 136 and 152; Fahey 2004.

220 Interviews 159 and 136.

221 Interview 191. See the reference to 'the claimant is a voluntary organisation of modest means' as a reason to refer in first instance and promptly, Western Sahara Campaign UK v HMRC and The Secretary of State for Environment, Food and Rural Affairs [2015] EWHC 2898 (Admin), para 5.

222 Interview 133. 
a legal basis in Dutch law. A reference had no immediate consequences for the beneficiary, because Somvao would not suffer from the delay as the allegedly unlawfully awarded subsidy had not yet been recovered. ${ }^{223}$ An additional reason to refer in Daimler was that costs 'would not be substantial', since the proceedings needed to be stayed in any case. ${ }^{224}$ The UK High Court likewise rejected the argument against a reference as the procedure would not 'cause substantial hardship, or prejudice to the rights of anyone'. ${ }^{225}$

Two Dutch migration judges noted that they avoid using the applicant's case as an instrument to address a principled matter if there is a high probability that the applicant will eventually lose and thus will not personally benefit from it. ${ }^{226}$ One lower court judge, for example, noted that judges should be careful in referring a legal question if this is not aimed at helping an asylum seeker. This judge suggested that he/she would never have referred Ghezelbash, which concerned the right to an effective legal remedy under the Dublin III Regulation. ${ }^{227}$ The outcome was uncertain and could also run against the interests of the asylum seeker. Indeed, this ultimately happened after the reference and a Grand Chamber judgment that was generally welcomed by migration lawyers as providing a high(er) level of fundamental rights protection: the referring lower court ruled in favour of Ghezelbash, but the decision was annulled by the Council of State, leaving the applicant himself without a temporary asylum residence permit. ${ }^{228}$

In addition to a preference for avoiding delay, judges also consider the consequences of a reference for other pending cases. This was considered in particular by the Dutch highest administrative courts in relation to migration. Former President of the Aliens Chamber of the Council of State Verheij stated that a responsible judge will take into consideration the consequences of such a delay. ${ }^{229}$ In the field of migration, there are often many - possibly hundreds - of cases in which the same question is discussed. ${ }^{230}$ Dutch judges acknowledged that justice would grind to a halt if every question of EU law about which

${ }^{223}$ Case C-599/13 Somvao EU:C:2014:2462; Interview 91.

224 Daimler AG v MOL (Europe Africa) Ltd \& Ors [2019] EWHC 3197 (Comm), para 132.

225 Wilkinson, $R$ (on the application of) $v$ South Hams District Council \& Anor [2016] EWHC 1860 (Admin). Cf Hemming (t/a Simply Pleasure Ltd) \& Ors, R (on the application of) $v$ Westminster City Council (Rev 1) [2013] EWCA Civ 591, para 66.

226 Interviews 14 and 22. Cf Pollack 2017, 585.

227 Case C-63/15 Ghezelbash EU:C:2016:409.

228 NL:RVS:2017:1326; Interview 22.

229 Verheij 2016, 83. Cf Storey et al 2014, 13.

230 Interview 14. See also NL:RVS:2011:BR3771, para 2.8.4; Sevenster and Wissels 2016, 92; Groenendijk 2015. 
there was some doubt were immediately referred to the ECJ. ${ }^{231}$ The judges stated that it would be undesirable if so many cases were put on hold indefinitely while a reference was made. ${ }^{232}$ For example, this consideration played a role in the cases on the intensity of review of the credibility assessment of asylum claims in relation to Article 46(3) of the Asylum Procedures Directive. The Council of State explicitly acknowledged that the text of Article 46(3) of the Procedures Directive did not provide a definitive answer, and noted that as yet there was no ECJ case law that clarified this provision. ${ }^{233}$ Nonetheless, the Council deliberately decided not to refer because it would otherwise 'have to shut down', as these questions went to the core of its work and would imply that a very large number of cases would have to be put on hold.

The consequences for other pending cases also play a relatively important role in the criminal law sphere. One notorious decision of the Dutch Criminal Chamber not to refer is its post-Salduz judgment, regarding the right to legal assistance during a police interrogation. The Supreme Court explicitly stated, as a reason for its decision, that a reference precludes 'an effective and expeditious' criminal justice system, and would result in a 'long lasting and unacceptable' delay for many cases in which the same issue played a role. ${ }^{234}$ Hence, the Criminal Chamber's relaxed approach to its obligation to refer stems from a robust perception that criminal proceedings do not allow for delays - not even of two to three months, as in the context of a PPU. One Supreme Court judge held that a reference inevitably infringes the right to a fair trial within a reasonable time, as a result of which the sentence must be reduced. As judges consider this difficult to explain to the wider public, criminal law judges exercise self-restraint when it comes to referring and instead take it upon themselves to apply (and sometimes interpret) EU law. ${ }^{235}$

This notwithstanding, however, a reference is sometimes unavoidable where the question of EU law cannot be answered by the national court itself. A good example is the Dutch Council of State's reference in relation to the so-called Nitrogen PAS programme, despite the major social and economic consequences that would result. This very complex and technical case dealt with the question of the compatibility of this programme with Article 6(3) of the Habitats Directive. The PAS allowed for the authorization of nitrogen deposits in Natura 2000 protected sites based on an 'appropriate assessment' carried out in advance in light of an overall amount of nitrogen deposits

231 Interviews 10 and 18.

232 Interviews 14, 18, 39 and 83; Sevenster and Wissels 2016, 90.

233 NL:RVS:2016:890-891, para 5.2.

234 NL:HR:2015:3608.

235 Three Dutch Supreme Court judges interviewed by Claassen ( $\mathrm{PhD}$ forthcoming in 2022). 
deemed compatible, instead of an individual assessment. ${ }^{236}$ It was problematic that the PAS anticipated the future positive effects of measures for protected nature areas and authorized deposits without any certainty that the planned measures would actually produce positive results. The Council of State eventually followed the ECJ judgment and concluded that the PAS was inconsistent with the Directive. The consequences of this judgment were significant and many building, farming and infrastructure projects had to be stopped. ${ }^{237}$ Prime Minister Rutte referred to the 'Nitrogen crisis' as the biggest challenge in his ten-year tenure - at least before the COVID-19 pandemic.

In sum, this section shows that the decision (not) to refer often boils down to a complex balancing exercise which weighs the importance of the EU law question against the consequences of a reference both in the case at hand and for other pending cases. If the legal issue is too important, the courts are more reluctant to refer, in order to minimize the risk of other cases being affected.

\subsubsection{Expected answer and pending cases}

At times, in deciding whether (not) to refer, courts also consider what happens at the ECJ. Two issues may be identified here. The first is the expected answer of the ECJ and the possibility of framing the legal question in an intelligible way. Implicit in many decisions not to refer in light of the expected answer is the notion of feedback loops - the focus of the fourth research question in this book (Chapter 8, section 1.4). The decision not to refer may also be influenced by previous experience with the ECJ. Second, other pending references and cases before the ECJ also affect the decision (not) to refer.

At times, courts have decided not to refer because they found it difficult to formulate a good question to which a useful answer could be given. For example, the UK High Court declined to refer Micula, which concerned the enforcement of an international investment arbitral award against Romania. It noted, among other things, that 'the questions to be referred on such a reference are not straightforward to identify'. ${ }^{238}$ A Dutch lower court judge recalled that he/she considered a reference about Article 15(c) of the Qualification Directive in relation to the notion of 'indiscriminate violence in situations of international or internal armed conflict' and the requisite level of violence necessary to establish subsidiary protection. He/she decided, however, that this question did not lend itself to a reference to the ECJ, because it would be almost impossible for the ECJ to come up with concrete and helpful guide-

236 Joined Cases C-293/17 and C-294/17 Coöperatie Mobilisation for the Environment UA and Vereniging Leefmilieu EU:C:2018:882.

237 Interview 10; Stichting Werkgroep Behoud de Peel v College van Gedeputeerde staten Noord-Brabant NL:RVS:2017:1259, para 29.5.

238 Micula \& Ors $v$ Romania \& Anor [2017] EWHC 31 (Comm). 
lines. ${ }^{239}$ Judges sometimes considered whether they would be able to explain the legal problem clearly to the ECJ within the maximum 20 pages allowed for references, especially considering that ECJ judges are unfamiliar with their legal systems. ${ }^{240}$ These considerations played a role in the cases discussed earlier about the intensity of review of the credibility assessment of asylum claims (section 3.5). ${ }^{241}$ The judges interviewed held that it would be difficult for the ECJ to deal with such a principled issue relating to the relationship between the judiciary and the administration - even more so given the widely diverging views on this issue within the Netherlands itself, let alone within the EU, with its 28 different legal systems.

Similar considerations played a role in the HS2 case before the UK Supreme Court, about a challenge to the government's plan for a high-speed rail network introduced by way of a Bill in Parliament without an environmental impact assessment (EIA). ${ }^{242}$ The EIA Directive exempts projects adopted by a legislative act from the obligation to conduct an EIA; the question in this case was whether the requirements for this exemption had been met. The case thus touched on a delicate issue in the United Kingdom, where judicial review of legislative acts is not allowed, given the strong notion of parliamentary sovereignty. Lord Reed noted that, had a reference been made:

it would have been essential to explain the constitutional issue as clearly as possible, not only because it would be largely peculiar to the United Kingdom, but also because the Court of Justice might be unwilling to make any allowance for the UK's difficulty unless the constitutional principle was understood to be truly fundamental. ${ }^{243}$

This case was also discussed during the interviews. One former Supreme Court judge noted: 'We did not like what the ECJ had done.' There were fears that the ECJ would endorse the suggestion of British AG Sharpston that there was a domestic duty to review the adequacy of the legislative process which had resulted in the planning permission. This would run counter to UK law and especially parliamentary sovereignty. ${ }^{244}$ The UK Supreme Court was 'not

\footnotetext{
239 NL:RBDHA:2017:3443, para 5; NL:RBDHA:2017:5164.

240 Interviews 10 and 18.

241 NL:RVS:2016:890-891, para 5.2.

242 HS2 Action Alliance Ltd, $R$ (on the application of) $v$ The Secretary of State for Transport \& Anor [2014] UKSC 3. Kokott and Sobotta 2019, 117-19.

243 Reed 2014, 8-9. Lady Justice Arden subsequently demonstrated her approval for the Supreme Court's line of reasoning, which mirrored the approach of the German Constitutional Court in upholding the German Constitution and constitutional identity, Arden 2014, 34.

244 Cf Wind et al 2009, 77.
} 
enthusiastic' about this and certainly would not have wished to see the ECJ adopt this position. ${ }^{245}$ Such an outcome would lead to a 'constitutional clash' whereby the Supreme Court would not follow the ECJ and would probably argue that the ECJ judgment did not fall within the scope of the European Community Act $1972 .{ }^{246}$ The UK Supreme Court hence considered the legal issue clair, despite a feeling that the ECJ 'may have a different answer'. There was no doubt about the law, but only about what Luxembourg might say. ${ }^{247}$ Another example is Three Rivers, on a depositor's right to compensation following the collapse of a bank, which was decided by the House of Lords in 2003. The House dealt extensively with EU law and eventually arrived at its own interpretation, which was subsequently adopted by the ECJ in a different German reference. Arnull noted that the House might have been reluctant to refer such a complex case dealing with questions that were far from being clair or eclairé. He thus commended the House for showing 'a remarkable grasp of Community law'. ${ }^{248}$

The previous account illustrates that courts - and once again, the UK and Dutch courts in particular - do not always consider it useful or time efficient to refer where they expect that the ECJ will respond only with criteria that are very general and already known. ${ }^{249}$ This happens in particular in cases that touch on the proportionality of particular national measures in the light of EU law, since the ECJ often leaves such an assessment to the referring court. ${ }^{250}$ One Dutch judge thus observed that questions about such issues lead only to a 'detour' through the ECJ that is of little practical use, and are thus a 'subscription to frustration'. ${ }^{251}$ For example, the Tax Chamber of the Dutch Supreme Court decided not to refer partly because it expected an abstract answer ('no more than you already knew') in a case dealing with the abolition of a so-called 'exemption' from a tax on the import of coal used to generate electricity. The AG had recommended a reference on the question of whether the abolition of this exemption was contrary to Directive 2003/96 on the taxation of energy products and electricity, which allows for environmental policy considerations to be taken into account. The Supreme Court nonetheless expected that the ECJ would not provide any precise indications as to how serious environmental

\footnotetext{
245 Interview 264. One barrister (211) noted that Supreme Court sometimes does not refer out of concern for parliamentary supremacy.

246 Interview 264.

247 Interview 231.

248 Three Rivers DC v Bank of England (No 3) [2001] UKHL 16; [2003] 2 AC 1; Arnull 2010, 77-79.

249 Interviews 66, 72, 81 and 264.

250 Case C-548/15 De Lange EU:C:2016:850; Interview 81.

251 Interview 32.
} 
policy considerations can be taken into account and would leave that to national courts. ${ }^{252}$ It thus concluded that the abolition of the exemption was not contrary to the EU Directive. The Civil Chamber likewise considered a reference unnecessary in Becton, which concerned the reimbursement of legal costs and Article 14 of Directive 2004/48 on the enforcement of IP rights. There was a feeling that a reference would add little to the case law of the ECJ, and that the ECJ would simply say that the assessment was up to the national court. Hence, the judges decided not 'to sit around waiting for the ECJ like a bunch of anxious rabbits' ${ }^{253}$ In these recent cases, the Dutch courts exhibited the same self-assurance as the UK courts and confidently applied established EU law principles to new cases (section 3.2).

In deciding whether to refer, courts also consider pending cases before the ECJ. It is unsurprising that courts are generally reluctant to 'duplicate' references if similar questions are already pending before the ECJ. ${ }^{254}$ In Micula, a pending annulment procedure was an additional reason for the High Court not to refer. ${ }^{255}$ Likewise, the UK High Court refused to refer in a competition law case because it did not want to pre-empt the decision of the European Commission and the General Court. ${ }^{256}$ Nonetheless, courts sometimes considered it desirable to refer questions even though similar questions were pending before the ECJ, preferring to do so rather than simply to await the outcome. The UK High Court found it 'appropriate' to refer Rosneft, even though an annulment case was already pending before the General Court challenging the Council's restrictive measures on access to the capital market for certain Russian entities operating in the oil sector, in view of Russia's actions which had destabilized the situation in the Ukraine. ${ }^{257}$ The rationale was to ensure that the High Court would not await the outcome of these annulment proceedings in vain in case the ECJ declared them inadmissible on procedural grounds and thus did not rule upon the merits. ${ }^{258}$ The UK High Court likewise decided to refer cartel damages case Daimler even though the same questions had

252 NL:HR:2018:862; Interviews 30 and 78.

253 Becton v Braun NL:HR:2018:721; Interview 27.

254 JTI Ireland v Minister for Health [2015] IEHC 481, paras 7-8; Hutchinson v Mapfre Espana Compania De Seguros Y Reaseguaros SA \& Anor [2020] EWHC 178 (QB), para 29; The National Council for Civil Liberties (Liberty), $R$ (on the application of) v SSHD \& Anor [2018] EWHC 975 (Admin), paras 113-16; SSHD v Watson \& Ors [2018] EWCA Civ 70, para 12.

255 Micula \& Ors $v$ Romania \& Anor [2017] EWHC 31 (Comm).

256 Roche Registration Ltd, $R$ (on the application of) $v$ The Secretary of State for Health (Rev 2) [2014] EWHC 2256 (Admin).

257 Case T-715/14 NK Rosneft \& Ors $v$ Council EU:T:2018:544.

258 PJSC Rosneft Oil Co v HMRC \& Ors [2015] EWHC 248 (Admin), paras 28 and 36. Cf $K$ And $A$ NL:RVS:2014:1196, para 27. 
already been referred by the Amsterdam District Court. As in Rosneft, the High Court pointed to the risk of the case being settled, as a result of which the reference would be withdrawn and the questions would go unanswered, with 'highly undesirable trial management and costs implications' ${ }^{259}$ There was also another reason for the court to refer: the reference would enable the UK court (and authorities) to present their perspective on the issue and respond to allegations of the referring Amsterdam District Court that a previous UK Court of Appeal judgment was wrong as a matter of EU law. ${ }^{260}$ The Dutch Council of State has also referred with the aim of 'feeding' its own view to the ECJ, even though similar cases were pending in Luxembourg. This happened, for example, in Dow Benelux on the Emissions Trading Scheme, in relation to which an Austrian court had already made a reference. ${ }^{261}$ Another example is $G$ and $R$, on the right to be heard in relation to the extension of the detention of illegally staying third-country nationals. ${ }^{262}$ The Tax Chamber of the Dutch Supreme Court had already asked similar questions about the right to be heard and the consequences of breach of those rights from the perspective of the rights of defence. ${ }^{263}$ The Council of State considered it necessary to refer this case to underline the differences between the context of the two different fields of law - customs and asylum. Moreover, the Council wanted a quick answer in $G$ and $R$ because the claimant was in detention. It therefore successfully submitted a question via the urgent preliminary ruling (PPU) procedure.

The Irish High Court likewise submitted a PPU reference even though there were also pending questions of the Supreme Court in a non-PPU case. A High Court judge even felt 'invited' to refer by that Supreme Court reference, which had been made in an EAW case: the Supreme Court could not make a PPU referral, since the person concerned was not in custody, whereas the High Court was confronted with a case in which similar issues arose with the procedural advantage of someone in detention. Once again, the rationale behind the reference was 'the sooner the better', because there was a feeling that 'nothing could move in the courts' ${ }^{264}$ This 'double' reference was made in relation to the question of whether the notification of the UK's intention to withdraw from the EU on the basis of Article 50 TEU meant that the Irish authorities must

259 Daimler AG v MOL (Europe Africa) Ltd \& Ors [2019] EWHC 3197 (Comm), para 132 .

260 Case C-819/19 Stichting Cartel Compensation \& Ors; Daimler AG v MOL (Europe Africa) Ltd \& Ors [2019] EWHC 3197 (Comm).

261 Joined Cases C-191/14, C-192/14, C-295/14, C-389/14 and C-391/14-C-393/14

Dow Benelux EU:C:2016:311.

${ }^{262}$ Case C-383/13 PPU G. and R. EU:C:2013:533.

263 Case C-437/13 Unitrading EU:C:2014:2318.

264 Interviews 152 and 155. 
refuse or postpone the execution of an EAW from the UK given the alleged uncertainty as to whether the rights enjoyed by those surrendered would continue to be protected after Brexit (answer: no). ${ }^{265}$ The Supreme Court hinted at a future referral in a PPU case and held:

it seems inevitable that, in the very near future, and in particular in the absence of the Court of Justice adopting the expedited procedure, a further case will come before the Supreme Court which would also require to be referred to the Court of Justice but where the person concerned was in custody. ${ }^{266}$

This quote also illustrates the Supreme Court's critique of the reluctant use of the expedited procedure by the ECJ, which basically forces national courts to opt strategically for PPU referrals. As will be mentioned in Chapter 5, section 4 , this issue was discussed during a meeting in Luxembourg between Irish Supreme Court and ECJ judges.

\section{CONCLUSION}

This chapter has shown that most judges operate in a pragmatic way and include pragmatic considerations in their decision (not) to refer. Pragmatism has also prevented courts from referring, especially where they believe that they themselves are equally well equipped to answer open questions of EU law or where they expect no useful answer from the ECJ. This sentiment is particularly strong among the confident UK Supreme Court judges. Other courts, such as the Dutch and Irish Supreme Courts, have adopted a more legal-formalist approach and are (more) faithful in adhering to the Article 267 TFEU and the CILFIT requirements. As will be further discussed in the next chapter, the Dutch lower courts are reluctant to refer because of their position as fact finders in the judicial hierarchy; whereas (most) of the Irish and UK lower courts apply a 'better sooner than later' logic to avoid unnecessary litigation.

Case C-327/18 PPU R O EU:C:2018:733; Case C-191/18 KN EU:C:2018:884.

266 Minister for Justice v O'Connor [2018] IESC 19, para 4.5; Minister for Justice v Dunne No 3 [2018] IEHC 283, para 16. 